4. Субъектность - индикатор эффективности социальной деятельности личности.

В структурно-системном подходе преобладает точка зрения, согласно которой алкоголизация личности зависит от целостной структуры качеств аддиктивной личности, таких как неудовлетворенные потребности, мотивы, отсутствие ценностей, интересов одобряемых обществом, направленности, в которых сочетаются наследственные факторы и внешние приобретенные. Такая структура личности определяет негативные отношения молодого человека к окружающим, обществу и самому себе, что приводит к нарушению социального развития, неудовлетворенным потребностям в познании себя, понимании другого и обеспечивает динамику алкогольного поведения.

Многообразие дефиниций «аддикции», социально-психологических подходов изучения молодежной алкоголизации свидетельствует о недостаточной изученности данного феномена и требует системного исследования. Из нашего краткого анализа видно, что данная проблема разрабатывается различными социально - психологическими направлениями.

* Исследование выполнено при поддержке гранта РГНФ номер 17-16-51002. $* * *$

1. Барденштейн, Л.М. Алкоголизм, наркомания и другие психические, и поведенческие расстройства, связанные с употреблением психоактивных веществ :учеб.пособие / Л.М. Барденштейн, А.В. Молодецких, Ю.Б. Можгинский, Н.И. Беглянкин, Г.А. Алешкина. - М. : ГЭОТАР - Медиа, 2015. - 96с.

2. Галяутдинова, С.И., Ахмадеева, Е.В. К проблеме понимания аддикции и зависимости отечественными и зарубежными исследователями [Текст] / С.И. Галяутдинова, Е.В. Ахмадеева // Вестник Башкирского университета. - № 1, Том 18, 2013.

3. Одинокова, В.А. Теоретическое и эмпирическое определение проблемного потребления алкоголя [Текст] / В.А. Одинокова // Теория и практика общественного развития. - №10. - 2014

4. Прялухина, А. В. Психология потребностной неудовлетворенности девиантно-развивающейся личности: феноменология и основы преодоления: монография / А. В. Прялухина. - М.: Буки Веди, 2013. $-347 \mathrm{c}$.

5. Х Хегенхан, Б. Теории научения / Б. Хегенхан, М. Олсон; [пер. с англ. Л. Бутылина и др.]. - 6-е изд. - СПб [и др.]: Питер, 2004. - 473 с.

\title{
Строгая О.Ю. \\ Социализация старости через произведения фольклорной и художественной литературы
}

(Россия, Москва)

doi: $10.18411 / \mathrm{sr}-10-12-2017-50$

idsp: 000001:sr-10-12-2017-50

Who helps people - he spends time in vain. Good deeds can not be glorified.

Помните знаменитую песенку старухи Шапокляк из мультфильма про Чебурашку: кто людям помогает, тот тратит время зря - хорошими делами прославиться нельзя... (Э. Успенский). Образ старушки, не хочется писать старухи, Шапокляк Э. Успенскому очень удался [6]- такая боевая, озорная и очень подвижная бабушка, но которая все время делала какие то пакости. Вот может поэтому она и запомнилась? Не зря говорят - хорошее забывается быстро, а плохое помнится долго.

Знаменитая русская Баба-Яга- Костяная нога [5], та которой пугают маленьких детей, и та отрицательная старушка(отрицательная крайность старости) с которой знакомятся все дети дошкольного возраста. Баба- Яга пришла к нам из русских народных сказок, из глубоких древних времен. Видимо это был один из первых 
прообразов зла, наряду с Кощеее Бессмертным и Змеем Горынычем. Так чем же прославилась эта бабушка-

- костяной ногой (нога скелета или нога мертвеца- из русской народной сказки «Перышко Финиста Ясна Сокола»: - ...Вошла она в избушку, видит, а в ней лежит баба-Яга, костяная нога из угла в угол, губы на полке, а нос в потолок врос);

- ступа, как средство передвижения (знаменитое изобретение древности наряду с ковром-самолетом - из русской народной сказки «Василиса Прекрасная»: - Скоро послышался в лесу страшный шум6 деревья трещали, сухие листья хрустели, въехала из леса Баба-Яга - в ступе едет, пестом погоняет, помелом след заметает);

- способностью направлять действия диких животных и птиц;

- тем, что воровала маленьких детей и запекала их в печи;

- и самое главное - она была очень старая и очень страшная.

Древнеславянские люди жили общинами и, соответственно, те люди, которые уходили по каким-то причинам из общины жить обособленно, автоматически становились непонятными, а все, что непонятно, то страшно и опасно. Чаще всего обособленно жили знахари, ворожеи или ведуньи. Так вот, и Баба-Яга могла быть и опасной, и непонятной, но и полезной - она могла дать совет, способствующий достижению цели. Это своеобразное не отрицание мудрости старости.

Скорее всего, не принятие одиночества, скупости, накопительства и агрессивной враждебности дали возможность зарождению таких персонажей как - Баба-яга, Кощеей бессмертный и Змей Горыныч.

Даже знаменитый образ современного доброго и благодушного Деда Мороза не всегда был таким. Ему предшествовал и образ неукротимого и свирепого славянского бога Позвизда (в славянской мифологии - страшный ветер, считается свирепым богом бури, сильного ветра), и мрачного бога подземелья Карачуна (славянское божество нижнего мира, повелитель морозов, холода и мрака), и достаточно жестоких древнеславянских богов Зимника и Мороза. Только с появлением христианских святых, появился более положительный Дед Мороз - им стал прообраз св.Николая (в христианстве почитается как чудотвореч, является покровителем путешествующих, заключенных и сирот).

Русских народных сказок, посвященных старости очень мало, в основном сказки заканчиваются свадьбой главных героев и тем, что потом они жили долго и умерли в один день. Самая знаменитая сказка про житие во старости - сказ про Старика и золотую рыбку. Но это уже не русская народная сказка, а сказка, написанная знаменитым русским поэтом А.С.Пушкиным [4], и в основном она не про счастливую старость, а про завышенные амбиции одного из супругов.

Не так много литературных произведений, где главные герои- пожилые люди. Самая знаменитая из литературных старух- мисс Джейн Марпл Агаты Кристи (писательница посвятила мисс Марпл около пятнадиати произведений)- старая, умная, традиционная английская леди. Знаменитая писательница списала ее со своей бабушки, и наделила ее любознательностью, общительностью, остротой ума и ясностью сознания. Получилась такая почти идеальная старушка, которая не жалуется на здоровье; которая живет в гармонии со своей старостью и обладая прекрасным аналитическим складом ума, расследует сложные криминальные преступления [7]. Так как же кто людям помогает....? Потому что, не возраст определяет цену человека (цитата из х/фильма Старики-Разбойники), а:

- социальная направленность;

- наличие целеполагания;

- прекрасная сохранность интеллекта. 
Получается такая своеобразная положительная крайность старости. Соответственно, запоминаются две крайности - или положительная или отрицательная. Старость, отягощенная физиологическими, психосоматическими болезнями, запоминается плохо - болел человек, ему было тяжело, но потому что cmaрость наступила. Такое в большинстве общественное мнение.

Общественные ценности, и соответственно отношение к старости у каждой народности свое. У бельгийской писательницы Амели Нотобм в произведении «Токийская невеста» [3] есть такой замечательный текст, описывающий японских стариков Каждое мое слово, каждый жест вызылвали у них дикий хохот. Они гримасничали, хлопали по спине внука, потом меня, пили чай из моей чашки. Старуха коснулась моего лба, закричала: «Ой, какой бельй!», и скорчилась от смеха, как и ее муж..... Я расспросила знакомых и выяснила, что в Японии такое происходит сплошь и рядом. В этой стране, где люди всю жизнь должнь неукоснительно держать себя в руках, к старости они довольно часто не выдержсивают, и у них сносит крышу, что не мешает им жить в семье, где за ними согласно обычаям, заботливо ухаживают.

Таким образом, среда, также как и семейные ценности формируют молодость зрелость, и закладывают своеобразный фундамент старости.

В 1951 году вышла повесть- притча знаменитого американского писателя Эрнеста Хемингуйя «Старик и море». Эта повесть была посвящена упорной , героической борьбе за свою мечту - поймать самую большую рыбу всей своей жизни. Когда Хемингуэй говорил, что ему повезло в том, что он нашел хорошего старика, он имел в виду не только хорошие душевные качества своего героя [1]. Старик хорош не только своей добротой, простодушием и смирением, под которым подразумевается умение жить в согласии с самим собой. В старике есть нечто более значительное подлинный и естественный героизм. На долю старика выпало тяжелейшее испытание. Он ведет свою титаническую борьбу с этой невиданной рыбой один на один, как и положено герою. И поединок этот со всеми его перипетиями, когда победа склоняется то на одну, то на другую сторону, все больше начинает напоминать миф. Герой должен вести борьбу в одиночестве, только тогда у него появляется возможность раскрыть себя полностью, проявить все свое мужество, стойкость, отвагу, умение. Старик знает свою физическую немощность, но он знает и другое - что у него есть воля к победе. «Я все равно ее одолею,- - сказал он,- при всей ее величине и при всем ее великолепии. Хоть это и несправедливо,- прибавил он мысленно,- но я ей докажу, на что способен человек и что он может вынести».

Находясь один в море, старик размышляет об одиночестве. «Нельзя, чтобы в старости человек оставался один,- думал он.- Однако это неизбежно». Но потом сам себя опровергает,- уже на обратном пути к дому старик думает о своих земляках: «Надеюсь, что они там зря не волнуются. Волноваться, впрочем, может только мальчик. Но он-то во мне не сомневается! Рьбаки постарше - те, наверно, тревожатся. Да и молодье тоже,- думал он.-Я ведь живу среди хороших людей». Впервые его герой не одинок в этом враждебном и жестоком мире! Впервые его герой достиг гармонии с природой и людьми, окружающими его, обрел согласие с самим собой. Долгий путь пришлось пройти хемингуэевскому герою, чтобы прийти к такому жизнеутверждающему итогу [8].

Коринфский Аполлон Аполлонович [2] в своей книге, написанной еще в 1901году, посвящает молодости и старости целую главу- Не все состарившиеся люди делаются брюзгливыми ворчунами, обличителями всего молодого-нового, то и дело повторяющими свое излюбленное словио «Ньнче молодежь- погляди да брось!» Много и таких, что, просветлев разумом на склоне лет, становятся и более чуткими сердием, более склонными к всепрощению и всепониманию. Как современно это звучит. 
Есть ли место подвигу (всепрощению и всепониманию) в старости? Конечно. Преодолевая физическую немощь, борясь с болезнями и душевными расстройствами, пожилые люди доказывают свое право на жизнь, ведь они живут среди хороших людей.

$$
* * *
$$

1. Грибанов Б.Т. Э.Хэмингуэй. Избранное - М.: Просвещение, 1987

2. Коринфский А.А. Народная Русь, Репринтное издание- Воронеж, Град Китеж, 1995

3. Нотомб А. Токийская невеста. Роман - М.: Иностранка, Азбука-Аттикус, 2011

4. Пушкин А.С. Сочинения в 3-х т. Т.1 Стихотворения. Сказки. Руслан и Людмила Поэма.- М.: Худож. лит., 1985

5. Русские народные сказки.- М.: Правда, 1985

6. Успеский Э. Крокодил Гена и его друзья.- М.: Планета детства, 2010

7. https://ru.wikipedia.org/wikip.Агата Кристи и мисс Марпл

8. http://hemingway-lib.ru/analiz-proizvedenii/gribanov-analiz-povesti-starik-i-more-ernesta-khemingueya.html 